\title{
The Role of Lofexidine in Management of Opioid Withdrawal
}

Joseph V. Pergolizzi Jr. • Hani Annabi • Christopher Gharibo •

Jo Ann LeQuang

Received: November 1, 2018 / Published online: December 18, 2018

(c) The Author(s) 2018

\section{ABSTRACT}

Fear of withdrawal symptoms has been cited by survey respondents as the main reason that they continued to use opioids. Lofexidine is an $\alpha_{2^{-}}$ adrenergic agonist that decreases the sympathetic outflow that results in the characteristic symptoms of opioid withdrawal. A structural analog of clonidine, lofexidine has a higher affinity and specificity for the $\alpha_{2 \mathrm{a}}$ receptors and does not reinforce opioid dependence. Withdrawal symptoms correlate approximately to the half-life of the opioid; patient factors such as age, duration of opioid exposure, physical status, and other considerations may influence the nature and duration of withdrawal symptoms. For patients with opioid use disorder and psychiatric comorbidities, withdrawal may be destabilizing and may exacerbate mental health status. Lofexidine has been shown in clinical trials to be safe and effective in helping to manage the symptoms of withdrawal and has been recommended in guidelines for this

Enhanced Digital Features To view enhanced digital features for this article go to: https://doi.org/10.6084/ m9.figshare.7429106.

J. V. Pergolizzi Jr. · H. Annabi · J. A. LeQuang ( $\bowtie)$ NEMA Research, Inc., Naples, FL, USA

e-mail: joann@leqmedical.com

C. Gharibo

Pain Medicine, NYU Langone Health, New York, NY, USA purpose. Adverse events associated with lofexidine include QT prolongation, hypotension, orthostasis, and bradycardia. The maximum course of treatment is 14 days, and doses should be titrated, with the recommended maximum dose to coincide with the most severe withdrawal symptoms (about 5-7 days after opioid discontinuation).

Keywords: Lofexidine; Opioid tapering; Opioid rehabilitation; Opioid use disorder; OUD; Opioid withdrawal; Tapering; Withdrawal

\section{INTRODUCTION}

Treating opioid dependence reduces the harms suffered by individuals with opioid use disorder (OUD) and benefits their communities. There are three broad phases in the treatment of people with OUD, but not all individuals will undergo all three phases. The first step is stabilization, also known as opioid maintenance, opioid substitution, or opioid management, during which the patient is rotated to a specific opioid (methadone or buprenorphine) in such a way that the patient's ongoing opioid use prevents withdrawal symptoms but also divorces the patient from the psychoactive effect characteristic of many opioids. Opioid maintenance gradually separates the patient's opioid use patterns from his or her mental states, moods, 
and cravings, and diminishes the opportunistic use of opioids, such as the profound urge to use opioids in the company of certain other people or in specific circumstances. After stabilization, opioids may be discontinued in detoxification ("detox"), which can be described as clinically managed withdrawal. Managing withdrawal symptoms is an important element of detoxification, but detoxification in and of itself is not a final treatment for drug dependence, in that patients may relapse after detox. The third and final step in overcoming OUD is rehabilitation, which may be viewed as the prevention of relapse [1]. OUD is a chronic, relapsing condition for which there is no cure. Many inpatient rehabilitation centers and community outpatient groups focus on rehabilitation, that is, preventing relapse.

Withdrawal symptoms can be terrifying to opioid-dependent individuals. The healthcare profession cannot afford to trivialize the extreme anxiety, fear, aversion, and withdrawal pain, even in those who sincerely and urgently wish to stop taking opioids. In a survey of 653 respondents enrolled in the Prescription Opioid Treatment Study, participants said the main reason that they continued to use opioids was to avoid withdrawal symptoms. In fact, regardless of whether the opioid users took the drugs as prescribed for chronic pain or for other (recreational, psychological) purposes, avoiding withdrawal was the main reason for continued opioid use [2]. For that reason, withdrawal mitigation strategies must be a key component in treating OUD.

Pharmacologically managed detoxification programs may be valuable in aiding patients and their caregivers in overcoming opioid withdrawal. Lofexidine, long available in Europe, has recently been approved for use in the United States for this important purpose. Lofexidine hydrochloride is intended for use in mitigating acute withdrawal symptoms associated with opioid dependence and facilitating a comprehensive program for opioid cessation. Despite the promise of lofexidine, it must be noted that OUD is a chronic relapsing condition for which there is no cure.

\section{METHODS}

This is a narrative and not a systematic review. On September 20, 2018, the authors searched the PubMed database for the keyword "lofexidine" and retrieved 183 results. The majority of these articles were found to be $>10$ years old, dating as far back as 1979 , so an age delimiter of 10 years was used, and 45 articles were obtained. When we excluded articles not in English, those that compared lofexidine to traditional Chinese medicine, correspondence, editorials, and articles that did not address the role of lofexidine specifically in managing withdrawal symptoms, the result was 20 articles. However, because lofexidine is both an "old" and a "new" drug (new to the USA but well established in Europe), we did draw on many of the older articles in the preparation of the pharmacology section. We also searched the bibliographies of particularly relevant articles for supplemental or support materials. We used web content to supplement our research as well.

It should be noted that many studies used test instruments to measure opioid withdrawal symptoms. The Opiate Withdrawal Scale (OWS) is a 32-item questionnaire that assesses the severity of opioid withdrawal symptoms. The Short Opiate Withdrawal Scale (SOWS)-Gossop, a more straightforward tenitem questionnaire, derives from the OWS. The SOWS-Gossop scale was validated in a clinical trial that showed it had good psychometric properties and was an appropriate, precise, and sensitive metric $[3,4]$. Other instruments used were the Modified Himmelsbach Opiate Withdrawal Scale (MHOWS), the Objective Opioid Withdrawal Scale (OOWS), and the OOWS-Handelsman survey. There has not yet emerged a clear "gold standard" instrument for the assessment of opioid withdrawal symptom intensity.

This article is based on previously conducted studies and does not contain any studies with human participants or animals performed by any of the authors. 


\section{THE PHARMACOLOGY OF LOFEXIDINE}

Lofexidine is an $\alpha_{2}$-adrenergic agonist that decreases the sympathetic outflow that leads to withdrawal symptoms, although it is not an effective antihypertensive [5]. It may not affect all withdrawal symptoms, as withdrawing patients taking lofexidine may still experience aches, pains, insomnia, and disrupted sleep [5]. As a centrally acting $\alpha_{2}$-adrenergic receptor agonist, lofexidine shows a high affinity for the $\alpha_{2 \mathrm{a}}$-receptor subtype [6]. The $\alpha_{2 \mathrm{a}}$-receptor is found near the synaptic cleft on both presynaptic and postsynaptic adrenergic and cholinergic neurons. Upon binding of an agonist, typically endogenous norepinephrine, the $\alpha_{2 a^{-}}$ receptor inhibits sympathetic (SNS) outflow, allowing the parasympathetic (PNS) branch of the autonomic nervous system to dominate neurological signaling, which will induce various physical manifestations. The $\alpha_{2 \mathrm{a}}$-receptor is an inhibitory G-protein-coupled receptor. Upon substrate binding, the receptor inactivates the enzyme adenylyl cyclase, thereby reducing the conversion of adenosine triphosphate (ATP) to cyclic adenosine monophosphate (cAMP) and preventing activation of the phosphorylation cascade needed to activate a variety of enzymes and proteins. In terms of treating opioid toxicity, it is important to keep in mind that $\alpha_{2 \mathrm{a}^{-}}$ receptors ultimately provide a form of negative feedback for the sympathetic branch of the autonomic nervous system [7].

To better understand the efficacy of lofexidine in treating opioid poisoning, one must understand the effects of opioid poisoning and withdrawal. Chronic opioid use suppresses noradrenergic outflow from the locus coeruleus of the pons, which acts as a major source of norepinephrine for the central nervous system (CNS) $[8,9]$. Therefore, during an opioid overdose, SNS neurotransmitters are suppressed, allowing the PNS to predominate. This leads to hypotension, bradypnea, and subsequent hypoxia to the CNS, greatly increasing the odds of mortality. During acute opioid withdrawal, adrenergic outflow from the locus coeruleus is restored, resulting in a sudden increase in norepinephrine and overstimulation of adrenergic neurons. This leads to various physical manifestations characteristic of opioid withdrawal-hypertension, tachycardia, diaphoresis, nausea, and vomiting, among other symptoms $[8,9]$. Withdrawal occurs with overactivation of the SNS, and toxicity occurs with overaction of the PNS. Lofexidine allows the PNS to predominate, which on the one hand reduces withdrawal symptoms, but on the other hand is similar to what occurs during opioid poisoning. Current pharmacological treatment can help in managing the symptoms associated with over-activation of the SNS by binding the $\alpha_{2 \mathrm{a}}$-receptor and, in this way, reducing sympathetic outflow.

Common pharmacological treatments are intended to normalize autonomic outflow and counteract withdrawal symptoms. Methadone, an opioid analog and opioid receptor agonist, can be used as pharmacological therapy, but abuse potential and associated adverse effects make it a risky option [10]. In addition, $\alpha_{2 \mathrm{a}}$-receptor agonists such as clonidine or lofexidine are potential treatment agents. Lofexidine is a structural analog of clonidine, but it demonstrates a higher affinity and specificity for the $\alpha_{2 \mathrm{a}}$-receptor compared to clonidine, making it perhaps a more efficacious treatment for acute opioid withdrawal [11].

A pharmacokinetic profile has been elucidated through both animal and human data. Lofexidine is extensively absorbed, reaching peak absorption at approximately $3 \mathrm{~h}$ following oral administration [12-14]. The mean maximum serum concentrations upon oral administration of 1.2 and $2.0 \mathrm{mg}$ doses in healthy adult males were $1755 \pm 306$ and $2795 \pm 593 \mathrm{ng} / \mathrm{ml}$, respectively [14]. In stabilized opioid-addicted patients, $3.2 \mathrm{mg} /$ day was divided into four doses; the maximum serum concentration was $3242 \pm 917 \mathrm{ng} / \mathrm{ml}$ [7]. Lofexidine is metabolized primarily via oxygendealkylation, forming two inactive glucuronide metabolites [13]. Roughly $87-93 \%$ of the drug is renally excreted as either an inactive metabolite or unchanged drug. Research has shown a terminal half-life of approximately $12 \mathrm{~h}$ [13]. The absolute oral bioavailability of lofexidine is roughly $72 \%$, so about $28 \%$ of the orally 
administered dose is lost to first-pass metabolism in the liver [15]. Lofexidine toxicity has been studied in animal models [16].

In an open-label study of urine and plasma pharmacokinetics in opioid-dependent subjects, patients were stabilized on a dose of $100 \mathrm{mg}$ morphine for days 3 through 8 of the study. On days 9 through 16, patients were administered one of three doses of lofexidine: three patients received $0.8 \mathrm{mg}$ twice daily (BID), six received $1.2 \mathrm{mg} \mathrm{BID}$, and nine subjects were administered $0.8 \mathrm{mg}$ three times daily (TID). In this study, the half-life obtained from all groups was $12.1 \pm 6.3 \mathrm{~h}$, and steady state was achieved by the 15 th day. $\mathrm{T}_{\max }$ did not differ significantly among dose groups. The fraction excreted unchanged in the urine $(\mathrm{Fe})$ ranged from 0.01 to $34 \%$, but no statistically significant differences emerged for the various dosing groups by study day, and the coefficient of variation for the same group on the same study day was between 38 and $86 \%$ [17].

\section{A SHORT HISTORY OF LOFEXIDINE}

Lofexidine was approved for opioid detoxification in the United Kingdom and much of Europe in the 1990s [18], but only in 2018 was approved in the United States (Lucemyra ${ }^{\mathrm{TM}}$, US WorldMeds, Louisville, KY, USA) in a priority review by the Food and Drug Administration (FDA) [19]. This makes lofexidine the first nonopioid agent to be cleared for market release in the USA for control of symptoms associated with opioid withdrawal [19]. Lofexidine is chemically similar in structure to clonidine, another central $\alpha_{2}$-receptor agonist that has been used off-label for management of opioid withdrawal. Since lofexidine has been used in the UK and other parts of Europe for management of opioid withdrawal symptoms since 1992, there is a large body of practical experience as well as clinical data about its use [15]. As a non-opioid agent, lofexidine helps to mitigate withdrawal symptoms without reinforcing opioid dependence or exposing the patient to the risk of abuse. Its decades-long use in the UK has provided substantial real-world data in the target population in an estimated 290,000 treatments [15]. It should be noted that lofexidine is indicated for management of acute withdrawal symptoms in patients discontinuing opioids and not for medication-assisted maintenance treatment or long-term rehabilitation. Lofexidine is indicated for managing opioid withdrawal symptoms only; it is not approved for other types of withdrawal. In a study of rhesus monkeys, chronic administration of lofexidine (intravenous $0.1-0.32 \mathrm{mg} / \mathrm{kg} / \mathrm{h}$ ) appeared to potentiate the reinforcing effects of cocaine, suggesting that it would likely be ineffective in treating cocaine withdrawal, and might even increase the risk for cocaine abuse in polydrug abusers [20].

\section{OPIOID WITHDRAWAL}

OUD is characterized by an altered brain biochemistry that leads to physiologic dependence on opioids, which promotes a vicious cycle of escalating use of opioids and worsening dependence. Physiologic dependence on opioids may occur in as few as 10 days in some individuals. The abrupt cessation of opioids leads to uncomfortable, distressing, and fearinducing withdrawal symptoms ("dope sickness") well known among persons with OUD. Opioid withdrawal, like OUD, may be best described as a continuum. Some individuals may be able to discontinue opioids without medical intervention, while others may experience moderate to severe or even very severe withdrawal symptoms. At its most extreme, acute withdrawal from opioids is potentially life-threatening. Symptoms include nausea, vomiting, diarrhea, abdominal cramps, myalgia, lacrimation, mydriasis, piloerection, hyperhidrosis, agitation, insomnia, and anxiety. The onset and duration of withdrawal symptoms varies considerably among patients, but symptoms may commence as early as $12 \mathrm{~h}$ after the last dose (typical for short-acting opioids) to $30 \mathrm{~h}$ (more typical for extended-release opioids or transdermal opioids). The goal of pharmacological therapy during opioid withdrawal is to manage symptoms, reduce the intensity of drug cravings typical during withdrawal, and thereby improve treatment 
retention. Acute opioid withdrawal is accompanied by a powerful desire to take more opioids (and thus perpetuate the disorder). For that reason, managing withdrawal symptoms and the associated opioid cravings is vitally important for effective detoxification [21].

Symptoms may persist for up to 2 weeks; some patients experience somewhat different early symptoms (when the opioid is first discontinued), which change over time. The peak withdrawal symptoms typically occur 5-7 days after the last use of opioids. Lofexidine dosing can be scheduled so that patients take the maximum dose around this time, and the dose reduced in small increments thereafter [19]. The recommended maximum course of lofexidine treatment for opioid withdrawal is 14 days.

The timeline for withdrawal symptoms may be roughly correlated to the opioid's half-life, that is, short-acting opioids such as heroin and morphine tend to be associated with a withdrawal characterized by sudden onset and shorter duration than that of longer-acting opioids [22]. Patient-related factors such as age, weight, physical status, overall health, comorbidities, and duration of opioid dependence may also influence the nature and severity of withdrawal symptoms. There may be other factors that contribute to the severity and distress associated with acute withdrawal symptoms that remain to be elucidated. For patients with comorbid mental health disorders (dual diagnosis), withdrawal can be destabilizing and, as such, exacerbate the mental health comorbidity.

In addition to persons seeking treatment for OUD, there are other occasions when withdrawal symptoms may occur. See Table 1. Withdrawal precipitated by an opioid antagonist, such as naloxone or naltrexone, may be more severe and can require inpatient care [21]. For example, a person who suffers opioid-induced respiratory depression and is rescued by naloxone may have rapid-onset withdrawal symptoms. In this situation, the patient may leave care against medical advice to obtain more opioids to halt the withdrawal symptoms or just to succumb to opioid cravings. Thus, an opportunity to effectively intervene in the care of a patient with OUD may be lost if withdrawal symptoms are not appropriately managed. Withdrawal may also occur when a patient is tapered to a lower dose of opioids but not discontinued altogether, or when the patient is rotated from a full-agonist opioid to a partialagonist opioid.

\section{SAFETY AND EFFICACY OF LOFEXIDINE IN CLINICAL TRIALS FOR MANAGING OPIOID WITHDRAWAL SYMPTOMS}

The FDA approval of lofexidine for management of acute withdrawal symptoms was based on two randomized double-blind clinical trials, of which one has been published to date. Using SOWS scores and treatment retention rates, lofexidine was compared with placebo in 866 adults dependent on short-acting opioids who were undergoing inpatient treatment for withdrawal [23]. A Cochrane meta-analysis of 26 randomized clinical trials $(n=1728)$ compared a variety of $\alpha_{2}$-adrenergic agonists, including lofexidine, either versus placebo or versus active comparators [24]. Both lofexidine and clonidine were more effective in reducing withdrawal symptoms than placebo, and the study concluded that lofexidine offered a better safety profile than clonidine. In the placebo-controlled trials, it was found that lofexidine and clonidine were associated with less severe withdrawal symptoms, longer patient time in treatment, and higher rates of treatment completion than placebo [24].

In a telephone survey of opioid detoxification centers, data were collected from 40 centers on nearly 1100 patients treated with lofexidine to manage withdrawal symptoms in a realworld clinical setting [25]. It was found that lofexidine dosing in this real-world setting was higher than manufacturer recommendations, with a mean starting dose exceeding the recommended $0.2-0.4 \mathrm{mg} /$ day in $54.7 \%$ of cases (mean starting dose per the survey was $0.8 \mathrm{mg} /$ day, median was $0.6 \mathrm{mg} /$ day, range $0.2-3.2 \mathrm{mg} /$ day), although the survey found no evidence that this higher starting dose influenced outcomes. The manufacturer 
Table 1 Clinical presentations in which a patient might benefit from lofexidine to support their efforts in discontinuing opioids

\begin{tabular}{|c|c|c|c|}
\hline Clinical presentation & Medical considerations & $\begin{array}{l}\text { Social/psychological } \\
\text { considerations }\end{array}$ & Comments \\
\hline $\begin{array}{l}\text { Pain patient who finds pain } \\
\text { worsened or not improved } \\
\text { by opioids }\end{array}$ & Opioid-induced hyperalgesia & $\begin{array}{l}\text { Need to find alternate pain } \\
\text { management strategies }\end{array}$ & $\begin{array}{l}\text { Patients with } \\
\text { hyperalgesia need/want } \\
\text { rapid detoxification }\end{array}$ \\
\hline $\begin{array}{l}\text { Pain patient who finds } \\
\text { opioid-associated side } \\
\text { effects intolerable }\end{array}$ & $\begin{array}{l}\text { Manage side effects, if } \\
\text { possible, but these will } \\
\text { resolve when opioids are } \\
\text { stopped }\end{array}$ & $\begin{array}{l}\text { Need to find alternate pain } \\
\text { management strategies }\end{array}$ & $\begin{array}{l}\text { Patients need/want rapid } \\
\text { detoxification, may be } \\
\text { impatient to get results }\end{array}$ \\
\hline $\begin{array}{l}\text { Opioid user who has medical } \\
\text { conditions that preclude } \\
\text { continuing opioid use }\end{array}$ & $\begin{array}{l}\text { Pregnancy, lactation, other } \\
\text { health considerations }\end{array}$ & $\begin{array}{l}\text { Pregnant women may require } \\
\text { special counseling to } \\
\text { understand the effects of } \\
\text { opioids on the fetus }\end{array}$ & $\begin{array}{l}\text { May require special } \\
\text { patient education }\end{array}$ \\
\hline $\begin{array}{l}\text { Recreational user who wants } \\
\text { to quit for personal, } \\
\text { business, financial, or } \\
\text { familial reasons }\end{array}$ & $\begin{array}{l}\text { Managing withdrawal, long- } \\
\text { term treatment }\end{array}$ & $\begin{array}{l}\text { Manage withdrawal and then } \\
\text { plug into appropriate } \\
\text { rehabilitation program }\end{array}$ & $\begin{array}{l}\text { Referral to rehabilitation } \\
\text { program (inpatient, } \\
\text { outpatient, } \\
\text { community-based) }\end{array}$ \\
\hline $\begin{array}{l}\text { Court-ordered or otherwise } \\
\text { mandated cessation of } \\
\text { opioid use }\end{array}$ & $\begin{array}{l}\text { Managing withdrawal, long- } \\
\text { term treatment }\end{array}$ & $\begin{array}{l}\text { High relapse rate, patients may } \\
\text { have other overwhelming } \\
\text { legal, financial, social, and } \\
\text { emotional problems }\end{array}$ & $\begin{array}{l}\text { Referral to appropriate } \\
\text { counseling or resources } \\
\text { to manage complex } \\
\text { problems }\end{array}$ \\
\hline $\begin{array}{l}\text { Chronic opioid patient who } \\
\text { is to be rotated, tapered, } \\
\text { and possibly discontinued } \\
\text { on advice of physician }\end{array}$ & $\begin{array}{l}\text { Dose-equivalence strategy, } \\
\text { tapering plan, managing } \\
\text { withdrawal }\end{array}$ & $\begin{array}{l}\text { Shared decision-making, } \\
\text { informed consent }\end{array}$ & $\begin{array}{l}\text { Tapering may take longer } \\
\text { in patients with longer } \\
\text { duration of opioid } \\
\text { exposure }\end{array}$ \\
\hline $\begin{array}{l}\text { Chronic opioid patient who } \\
\text { wants to stop taking } \\
\text { opioids for personal reasons } \\
\text { and seeks advice of } \\
\text { physician }\end{array}$ & $\begin{array}{l}\text { Managing withdrawal } \\
\text { symptoms, finding } \\
\text { appropriate plan to stop use }\end{array}$ & $\begin{array}{l}\text { Shared decision-making, } \\
\text { selection of individualized } \\
\text { options }\end{array}$ & $\begin{array}{l}\text { May be appropriate to } \\
\text { taper first and then } \\
\text { manage withdrawal in } \\
\text { long-term plan }\end{array}$ \\
\hline $\begin{array}{l}\text { Emergency rescue of patient } \\
\text { in opioid-induced } \\
\text { respiratory depression } \\
\text { (either street drugs or } \\
\text { prescription opioids) }\end{array}$ & $\begin{array}{l}\text { Emergency treatment; patient } \\
\text { may emerge agitated, } \\
\text { confused, belligerent. } \\
\text { Withdrawal may be } \\
\text { immediate and severe }\end{array}$ & $\begin{array}{l}\text { Medical advice to patient, } \\
\text { management of acute } \\
\text { withdrawal, counseling of } \\
\text { patient, possible emergency } \\
\text { hospitalization, shared } \\
\text { decision-making }\end{array}$ & $\begin{array}{l}\text { Explanation of lofexidine } \\
\text { treatment and close } \\
\text { supervision to help } \\
\text { patient go through } \\
\text { withdrawal }\end{array}$ \\
\hline
\end{tabular}


recommends a treatment duration of 14 days, but most patients in the survey stopped lofexidine treatment after 10 days; $60.4 \%$ of patients completed lofexidine detoxification successfully, while $39.6 \%$ of patients failed. The survey found data to suggest that patients taking diazepam or naltrexone along with lofexidine were more likely to succeed [25]. In addition, many centers appeared to be using a set dose of lofexidine rather than titrating the dose as recommended.

\section{PLACEBO-CONTROLLED STUDIES}

In a phase III randomized, multicenter, doubleblind, placebo-controlled 8-day study of 264 patients dependent on short-acting opioids, patients were randomized to treatment with lofexidine hydrochloride $3.2 \mathrm{mg}$ per day in four equal daily doses over the first 5 days and then two doses of placebo $(n=134)$ or placebo for the entire study $(n=130)$. Primary endpoints were SOWS-Gossop on the third day and time to dropout from the study. Secondary endpoints included the percentage of patients who completed the study, the area under the 5-day SOWS-Gossop time curve $\left(\mathrm{AUC}_{1-5}\right)$, and the OOWS-Handelsman, the Modified Clinical Global Impressions (MCGI) scale, and Visual Analog Scale for Efficacy (VAS-E) scores. The mean age of patients in this study was $36.8 \pm 10.9$ years, with $75.8 \%$ male, and the primary drugs of abuse were similar for both groups: heroin, oxycodone, and hydrocodone. The lofexidine group had significantly lower SOWS scores on day 3 compared to placebo patients (6.32 vs. 8.67, respectively, $p=0.0212$ ). Placebo patients were more likely to terminate the study early ( 80 vs. 59 patients, respectively) and those in the lofexidine group who dropped out tended to remain in the study longer than placebo-group dropouts $(p=0.0034)$. Secondary endpoints favored lofexidine over placebo, and lofexidine was well tolerated by the patients. Adverse events were reported by most patients in both groups (97.0 and $93.8 \%$ for lofexidine and placebo patients, respectively), but the adverse events significantly more likely to occur in the lofexidine group versus placebo $(p<0.01)$ were hypotension, dizziness, dry mouth, and bradycardia. In contrast, vomiting and lacrimation were significantly $(p<0.01)$ more likely to occur in placebo than lofexidine patients. Upon discontinuation of lofexidine, those subjects who experienced hypotension did not experience significant rebound hypertension [23].

In a double-blind placebo-controlled phase III study of 68 opioid-dependent patients at three sites undergoing detoxification, patients were randomized to receive lofexidine or placebo [26]. Patients were stabilized on opioids on days $1-3$ of the study, then underwent detoxification in either the lofexidine or placebo group (days 4-8), and then entered the postdetoxification phase (days 9-11). On day 5 of the study, lofexidine patients had significantly lower MHOWS scores than placebo patients $(p=0.0019)$ and significantly higher treatment retention rates than placebo patients $(38.2$ vs. $14.2 \%, p=0.01$ ) [26].

\section{COMPARATIVE STUDIES}

\section{Lofexidine Versus Clonidine}

A Cochrane systematic review and meta-analysis compared nine studies investigating an antagonist-adrenergic agonist combination composed mainly of an $\alpha_{2 \mathrm{a}}$-adrenergic agonist (lofexidine or clonidine) plus an opioid antagonist (naltrexone or naloxone) for managing withdrawal in opioid-dependent patients $(n=955)$. There were five inpatient studies and four outpatient studies (some with day care), but the studies were too heterogeneous to allow conclusions to be drawn. While investigators concluded that lofexidine and clonidine were feasible approaches to managing opioid withdrawal, they could not state whether one was superior to the other or whether either could reduce the duration of withdrawal [27].

\section{Lofexidine Versus Diazepam}

In a study from Singapore, 111 opioid-dependent patients were treated with a 10-day 
detoxification program and were randomized to treatment with lofexidine $(n=56)$ or diazepam $(n=55)$. Patients were evaluated using the OOWS for the primary endpoint on days 3 and 4 and the SOWS, opioid craving, and program retention rate for secondary endpoints. OOWS, SOWS, and opioid craving were consistently lower for lofexidine than diazepam patients at all measurement points in the 14-day study, but the difference was not statistically significant on days 3 and 4, which were considered to represent peak withdrawal symptoms. More lofexidine than diazepam patients completed treatment. The investigators concluded that lofexidine was at least as effective as diazepam in managing opioid withdrawal symptoms and treatment retention [28].

\section{SAFETY AND ADVERSE EVENTS}

In the phase III double-blind clinical trial used by the FDA for approval, the following adverse events were reported significantly more frequently in the lofexidine group than the placebo group: hypotension, orthostasis, bradycardia, dizziness, somnolence, sedation, dry mouth, and rebound elevations in blood pressure [23]. Bradycardia and orthostatic hypotension leading to study discontinuation occurred more often in women than men. Lofexidine appears to result in less hypotension than clonidine [27].

Lofexidine may prolong the QT interval on an electrocardiogram (ECG), and regular ECG monitoring is recommended for adults taking lofexidine if they have bradyarrhythmias, hepatic or renal dysfunction, or heart failure [19]. Coadministration of lofexidine with methadone appears to prolong the QT interval on the ECG [29]. In a study of 14 adults on methadone maintenance (target dose $80 \mathrm{mg} /$ day) stabilized for 3 weeks, patients received $0.4 \mathrm{mg}$ lofexidine daily or placebo for 1 week to be taken at the same time as methadone. In weeks 3 through 8 of the study, all subjects received lofexidine with dose escalation in $0.2 \mathrm{mg}$ increments, so that by the eighth week, patients were taking $1.6 \mathrm{mg} /$ day lofexidine along with methadone. ECGs were taken at baseline, at methadone stabilization, and after lofexidine administration. ECG results did not reveal any changes in heart rate or PR, QRS, or QT intervals at methadone stabilization, but heart rate decreased significantly once lofexidine was commenced (mean standard deviation $-8.0 \pm 7.3$ beats per minute, $p=0.0006$ ). Analyzed using maximal ECG response, the QT interval was prolonged by $21.9 \pm 40.8 \mathrm{~ms}$ $(p=0.018)$, and three subjects (all female) had a clinically significant QT interval prolongation of $>40 \mathrm{~ms}$ [29].

In a prospective double-blind study of 14 opioid-dependent adults (18-45 years), patients were stabilized on methadone maintenance (starting with $10 \mathrm{mg} /$ day and titrated upward based on tolerability and the individual patient to a target dose of $80 \mathrm{mg} /$ day) [30]. After a 3-week stabilization phase, patients were administered lofexidine or placebo at the same time as methadone. Lofexidine doses started at $0.4 \mathrm{mg} /$ day and were titrated upward in weekly $0.2 \mathrm{mg}$ increments to a target dose of $1.6 \mathrm{mg} /$ day. Five hours after each new dose of lofexidine, patients were monitored for orthostatic vital signs and adverse events. It was found that lofexidine significantly decreased sitting systolic and diastolic blood pressure ( $p=0.045$ and $p=0.033$, respectively) versus placebo, i.e., methadone without lofexidine. No significant alterations in orthostatic signs were observed with lofexidine. Lofexidine was associated with decreased cognitive efficiency, and higher doses of lofexidine were associated with poorer results in solving a mathematical problem compared to placebo ( $p=0.0035)$ [30].

In a survey of 40 opioid treatment centers, data were collected by telephone on approximately 1100 patients who underwent lofexidine detoxification in a real-world setting [25]. Of these patients, $32.7 \%$ experienced an adverse event, among which the most frequently reported were dizziness $(8.5 \%)$, hypotension $(7.5 \%)$, sedation $(6.6 \%)$, dry mouth $(5.3 \%)$, and bradycardia (3.9\%) [25].

\section{DRUG-DRUG INTERACTIONS}

Lofexidine should not be taken with other drugs that could result in bradycardia or hypotension, including (but not limited to) beta-blockers or 
calcium-channel blockers. If lofexidine is taken with other drugs that may prolong the QT-interval on the ECG (such as methadone), regular ECG monitoring is recommended.

Lofexidine is metabolized via the cytochrome P450-2D6 (CYP2D6) enzymatic system. Drugs that inhibit CYP2D6, such as paroxetine, can increase the patient's exposure to lofexidine by as much as $28 \%$ and may exacerbate side effects such as bradycardia or orthostatic hypotension [19].

\section{LOFEXIDINE IN THE GUIDELINES}

The National Collaborating Centre for Mental Health developed opioid detoxification guidelines which were published by the National Institute for Health and Care Excellence (NICE) in 2008, and reviewed them again in 2014; these NICE guidelines recommend lofexidine for management of opioid-associated withdrawal symptoms [31]. In addition, the World Federation of Societies of Biological Psychiatry (WFSBP) has issued guidelines for the biological treatment of substance use disorders, including opioid dependence. They found excellent evidence to support the use of methadone, buprenorphine, or a combination of buprenorphine/naloxone to treat opioid withdrawal, with clonidine and lofexidine as adjunctive agents. Opioid maintenance has been most thoroughly studied with methadone and buprenorphine, although it is possible to maintain opioid-dependent patients on heroin and naltrexone as second-line agents [32].

\section{CONSIDERATIONS IN CLINICAL PRACTICE}

Although lofexidine has only recently gained US approval, clinicians in the United States are benefiting from long experience with lofexidine in the treatment of acute withdrawal symptoms in European centers. It is an important new weapon in the US armamentarium against OUD, in that withdrawal symptoms represent a major impediment to opioid discontinuation and even to seeking treatment for OUD. Studies suggest that it is effective and better tolerated than clonidine, but there is a drawback in that it is considerably more expensive than clonidine [33].

Clinicians who work to help manage acute withdrawal in patients often do not have a large body of literature for research as to the best approaches for detoxification. Logistically speaking, detoxification may occur in an inpatient or outpatient setting, and to date there has been limited comparative study on the effectiveness or safety of these two settings on the course of treatment. In a study of 68 opioiddependent subjects who were on opioid-maintenance community-based programs (mainly but not exclusively on methadone), those who requested detoxification were randomized to undergo the program with lofexidine in an inpatient versus an outpatient setting. Although more inpatients than outpatients completed detoxification (18 vs. 12 , respectively), the between-group difference did not achieve statistical significance. The outpatient group received medication for a significantly longer period of time, and when the detoxification duration was controlled for, the inpatients had significantly better results. At 1 month, 11 participants (16\%) were opioidfree, and at 6 months, eight were opioid-free, but the results were not significantly different between groups [34]. Further study may be helpful in gaining a better understanding the most effective setting for opioid detoxification.

\section{DISCUSSION}

Opioid-dependent patients often cite their fear of withdrawal symptoms as the single most overwhelming barrier to treatment for OUD. Eliminating this impediment could substantially increase interest in opioid cessation. Acute withdrawal symptoms can vary widely in severity among people with OUD, and clinicians should not minimize them or discount the degree of fear they can instill. In some cases, opioid withdrawal can be a life-threatening condition. Clinicians who help opioid-dependent individuals navigate acute withdrawal find a paucity of resources at their disposal. There are 
few studies, few guidelines, little comparative literature, and not many tools at their disposal. In many cases, clinicians recommend what is available, not necessarily what works most effectively.

The importance of being able to help a patient safely and successfully pass through the acute withdrawal phase with manageable discomfort and distress cannot be overstated. A safe, relatively comfortable withdrawal period overcomes one of the most significant barriers to seeking treatment for OUD. The ability to transition a patient from a dependent to a nondependent state with minimal distress would make it possible for individuals to safely and confidently overcome OUD.

The role of lofexidine is important because it is an effective way to help blunt the effect of many acute withdrawal symptoms. Other treatment options should be considered as well, as withdrawal may also involve intense and upsetting levels of insomnia, anxiety, and fearfulness which may require adjuvant medications. Lofexidine is effective but may not fully address all of the associated aches and pain, arthralgia, myalgia, and headache. Opioid withdrawal can be intense and multifaceted, but it typically resolves in 2 weeks. Clinically supervised withdrawal management may make opioid cessation more achievable for individuals with OUD and prior bad experiences or overwhelming fear at the prospect of undergoing withdrawal.

The role of lofexidine is only one portion of the larger mosaic of successful opioid discontinuation. More research is needed to find the most effective and efficient ways for patients to discontinue opioids and avoid or at least reduce relapse. Those with OUD may have only sporadic intersections with the healthcare community, but these points of intersection may be crucial opportunities for the healthcare system and the community to intervene in meaningful ways to help break the terrible, destructive cycle of addiction. Thus, it is important for healthcare providers to be able to offer real-world, realistic, and available clinical solutions for overcoming addiction with confidence that these treatments are safe and effective. Lofexidine may emerge as an important non-opioid tool to help patients endure the extreme stresses of opioid withdrawal-arguably the greatest impediment to recovery-and to then proceed on an individualized path to recovery.

\section{CONCLUSION}

Lofexidine, long approved in many parts of Europe for the management of symptoms associated with acute opioid withdrawal, has recently been approved for use in the United States. Lofexidine can help mitigate the intensity of the many symptoms associated with opioid withdrawal and may help quell cravings for opioids during withdrawal. Studies have found it to be as effective as clonidine (which is structurally similar) but with a more favorable tolerability profile. Since acute opioid withdrawal is a major barrier to opioid cessation, lofexidine may be an important new weapon in the armamentarium against OUD. However, it must be noted that OUD is a serious and relapsing disorder.

\section{ACKNOWLEDGEMENTS}

Funding. No funding or sponsorship was received for this study or publication of this article.

Authorship. All named authors meet the International Committee of Medical Journal Editors (ICMJE) criteria for authorship of this article, take responsibility for the integrity of the work as a whole, and have given their approval for this version to be published.

Disclosures. Joseph V. Pergolizzi Jr., Hani Annabi, Christopher Gharibo, and Jo Ann LeQuang have nothing to disclose.

Compliance with Ethics Guidelines. This article is based on previously conducted studies and does not contain any studies with human participants or animals performed by any of the authors. 
Open Access. This article is distributed under the terms of the Creative Commons Attribution-NonCommercial 4.0 International License (http://creativecommons.org/licenses/ by-nc/4.0/), which permits any noncommercial use, distribution, and reproduction in any medium, provided you give appropriate credit to the original author(s) and the source, provide a link to the Creative Commons license, and indicate if changes were made.

\section{REFERENCES}

1. O'Shea J, Law F, Melichar J. Opioid dependence. BMJ Clin Evid. 2009;103:148-54.

2. Weiss RD, Potter JS, Griffin ML, et al. Reasons for opioid use among patients with dependence on prescription opioids: the role of chronic pain. J Subst Abuse Treat. 2014;47(2):140-5.

3. Vernon MK, Reinders S, Mannix S, Gullo K, Gorodetzky CW, Clinch T. Psychometric evaluation of the 10-item Short Opiate Withdrawal Scale-Gossop (SOWS-Gossop) in patients undergoing opioid detoxification. Addict Behav. 2016;60:109-16.

4. Wesson D, Ling W. The Clinical Opiate Withdrawal Scale (COWS). J Psychoact Drugs. 2003;35:253-9.

5. Gish EC, Miller JL, Honey BL, Johnson PN. Lofexidine, an \{alpha\}2-receptor agonist for opioid detoxification. Ann Pharmacother. 2010;44(2):34351 .

6. Drugs.com. Lofexidine hydrochloride. AHFS Monographs 2018. https://www.drugs.com/monograph/ lofexidine-hydrochloride.html. Accessed 2 Oct 2018.

7. Yu E, Miotto K, Akerele E, et al. Clinical pharmacokinetics of lofexidine, the alpha 2-adrenergic receptor agonist, in opiate addicts plasma using a highly sensitive liquid chromatography tandem mass spectrometric analysis. Am J Drug Alcohol Abuse. 2008;34(5):611-6.

8. Gold MS, Redmond DE Jr, Kleber HD. Clonidine blocks acute opiate-withdrawal symptoms. Lancet. 1978;2(8090):599-602.

9. Gold MS, Redmond DE Jr, Kleber HD. Clonidine in opiate withdrawal. Lancet. 1978;1(8070):929-30.

10. Gowing L, Farrell M, Ali R, White JM. Alpha2adrenergic agonists for the management of opioid withdrawal. Cochrane Database Syst Rev (Online). 2009;2:CD002024.
11. Cox S, Alcorn R. Lofexidine and opioid withdrawal. Lancet. 1995;345(8962):1385-6.

12. Midgley I, Chasseaud LF, Taylor T, Darragh A. The absorption and excretion of 14C-lofexidine hydrochloride in man. Arzneimittelforschung. 1982;32(8a):972-5.

13. Midgley I, Fowkes AG, Chasseaud LF, Hawkins DR, Girkin R, Kesselring K. Biotransformation of lofexidine in humans. Xenobiotica. 1983;13(2):87-95.

14. Al-Ghananeem AM. Pharmacokinetics of lofexidine hydrochloride in healthy volunteers. J Pharm Sci. 2009;98(1):319-26.

15. US WorldMeds L. Advisory Committee Lofexidine hydrochloride (Lucemyra) briefing document. Psychopharmacologic drugs advisory committee 2018. https://www.fda.gov/downloads/Advisory Committees/CommitteesMeetingMaterials/Drugs/ PsychopharmacologicDrugsAdvisoryCommittee/ UCM602419.pdf. Accessed 2 Oct 2018.

16. Tsai TH, Beitman RE, Gibson JP, Larson EJ, Friehe H, Fontaine R. Acute, subacute and chronic toxicity/carcinogenicity of lofexidine. Arzneimittelforschung. 1982;32(8a):955-62.

17. Al Ghananeem AM, Herman BH, Abbassi M, et al. Urine and plasma pharmacokinetics of lofexidine after oral delivery in opiate-dependent patients. Am J Drug Alcohol Abuse. 2009;35(5):311-5.

18. Vartak AP. The preclinical discovery of lofexidine for the treatment of opiate addiction. Expert Opin Drug Discov. 2014;9(11):1371-7.

19. Lofexidine (Lucemyra) for opioid withdrawal. Med Lett Drugs Ther. 2018;60(1551):115-7.

20. Kohut SJ, Fivel PA, Mello NK. Differential effects of acute and chronic treatment with the alpha2adrenergic agonist, lofexidine, on cocaine self-administration in rhesus monkeys. Drug Alcohol Depend. 2013;133(2):593-9.

21. Management of opioid withdrawal symptoms. Med Lett Drugs Ther. 2018;60(1554):137-41.

22. Farrell M. Opiate withdrawal. Addiction (Abingdon, England). 1994;89(11):1471-5.

23. Gorodetzky CW, Walsh SL, Martin PR, Saxon AJ, Gullo KL, Biswas K. A phase III, randomized, multicenter, double blind, placebo controlled study of safety and efficacy of lofexidine for relief of symptoms in individuals undergoing inpatient opioid withdrawal. Drug Alcohol Depend. 2017;176: 79-88. 
24. Gowing L, Farrell M, Ali R, White JM. Alpha(2)adrenergic agonists for the management of opioid withdrawal. Cochrane Database Syst Rev (Online). 2016;5:CD002024.

25. Akhurst JS. Lofexidine in opiate withdrawal: a safety and usage survey. Pharmacoepidemiol Drug Saf. 2000;9(1):43-7.

26. Yu E, Miotto K, Akerele E, et al. A phase 3 placebocontrolled, double-blind, multi-site trial of the alpha-2-adrenergic agonist, lofexidine, for opioid withdrawal. Drug Alcohol Depend. 2008;97(1-2): 158-68.

27. Gowing L, Ali R, White JM. Opioid antagonists with minimal sedation for opioid withdrawal. Cochrane Database Syst Rev (Online). 2017;5:CD002021.

28. Guo S, Manning V, Yang Y, et al. Lofexidine versus diazepam for the treatment of opioid withdrawal syndrome: a double-blind randomized clinical trial in Singapore. J Subst Abuse Treat. 2018;91:1-11.

29. Schmittner J, Schroeder JR, Epstein DH, Krantz MJ, Eid NC, Preston KL. Electrocardiographic effects of lofexidine and methadone coadministration: secondary findings from a safety study. Pharmacotherapy. 2009;29(5):495-502.
30. Schroeder JR, Schmittner J, Bleiberg J, Epstein DH, Krantz MJ, Preston KL. Hemodynamic and cognitive effects of lofexidine and methadone coadministration: a pilot study. Pharmacotherapy. 2007;27(8):1111-9.

31. National Collaborating Centre for Mental Health. Drug misuse: opioid detoxification: the NICE guideline. 2008. https://www.nice.org.uk/guidance/ cg52/evidence/drug-misuse-opioid-detoxificationfull-guideline-196515037. Accessed 2 Oct 2018.

32. Soyka M, Kranzler HR, van den Brink W, Krystal J, Moller HJ, Kasper S. The World Federation of Societies of Biological Psychiatry (WFSBP) guidelines for the biological treatment of substance use and related disorders. Part 2: Opioid dependence. World J Biol Psychiatry. 2011;12(3):160-87.

33. Expanded table: some drugs for management of opioid withdrawal symptoms. Med Lett Drugs Ther. 2018;60(1554):e144-e146.

34. Day E, Strang J. Outpatient versus inpatient opioid detoxification: a randomized controlled trial. J Subst Abuse Treat. 2011;40(1):56-66. 